\title{
Exploring and expanding transdisciplinary research for sustainable and just natural resource management
}

\author{
Margaret G. Wolff ${ }^{1}$, Jessica J. Cockburn $^{2}$, Chris De Wet $^{3}, \underline{\text { Joana Carlos Bezerra }}^{4}$, Matthew J. T. Weaver $^{1}$, Andiswa Finca $^{5,6}, \underline{\text { Alta De }}^{1}$
} ${\underline{V_{S}}}^{7}, \underline{\text { Mateboho M. Ralekhetla }}^{1}, \underline{\text { Notiswa Libala }}^{1}$, Qawekazi B. Mkabile ${ }^{1}$, Oghenekaro Nelson Odume $^{8}$ and Carolyn G. Palmer ${ }^{1}$

\begin{abstract}
Transdisciplinarity is gaining acceptance in sustainability science research as an approach to work across disparate types of knowledge and practices in order to tackle complex social-ecological problems. On paper, transdisciplinarity appears to be substantially helpful, but in practice, participants may remain voiceless and disadvantaged. In this paper, we retrospectively investigate four case studies using recent design principles for transdisciplinary research, to explore a deeper understanding of the practical successes and failures of transdisciplinary research engagement. We show that the transdisciplinary way of working is time consuming, challenging, and insists that researchers and participants contribute reflexively. Careful attention to research design and methodology is central. The acceptance that complexity renders knowledge provisional, and complete honesty about the purpose of the research are critical to building relationships between researchers and participants. Gaining an understanding of the values people hold influences the research process and the possible outcomes toward sustainable and just natural resource management. We suggest that in order to enable sustainable and just natural resource management, transdisciplinary research should include values and ethics in the design, implementation, and reporting of projects.
\end{abstract}

Key Words: complex social-ecological systems; ethics; reflexivity; sustainability science; transdisciplinarity; values

\section{INTRODUCTION}

Transdisciplinary (TD) research has found traction in sustainability science (Jahn et al. 2012, Swilling and Annecke 2012, Dedeurwaerdere 2013). Lang et al. (2012:26) define transdisciplinarity as "a reflexive, integrative, method-driven scientific principle aiming at the solution or transition of societal problems and concurrently, of related scientific problems by differentiating and integrating knowledge from various scientific and societal bodies of knowledge." The definition forms the basis for a set of four design principles for TD research practice that offers a sequential pathway: building a team; producing cocreated, solution-oriented, transferrable knowledge; effecting integrated implementation; and activities of adaptive evaluation, mitigating conflict, and enhancing participation that cut across the previous three principles (Lang et al. 2012). We use this definition and its associated sequential pathway as a comparative framing to interrogate research toward sustainable and just natural resource management in the Eastern Cape, South Africa.

A powerful driver for TD research comes from the widespread intractability of complex problems evident in the interactions between society and the biophysical world (Rockström et al. 2009). There is a well-developed conceptual and theoretical context for TD research as a necessary approach to transformative engagement with wicked social-ecological problems. General complexity theory (Cilliers 2000, 2001, 2006, Audouin et al. 2013, Cilliers at al. 2013, Preiser et al. 2013), with its articulation of the characteristics and implications of complex systems, provides a foundation (Palmer and Munnik 2018). Complex social- ecological systems (CSES; Folke 2006) have been strongly theorized in terms of resilience and the adaptive responses that emerge in complex systems (Biggs et al. 2012), while social and expansive learning (Engstrom 1987, 2001, Wals et al. 2009, Ison 2010, Sannino and Engeström 2017) demonstrate learning as a core adaptive process for engagement with social-ecological problems. Conceptual, theoretical, and design contributions are generally more evident in the TD, CSES, and learning literature, but feedback from practice is scarce.

Recent contributions from South Africa, in which researchers reflect on putting TD research into practice are surfacing (Van Breda and Swilling 2019). Cockburn et al. (2016) contribute to addressing challenges of building TD teams by focusing on the science-action gap. They demonstrate the care required to build trust relationships among multiple partners and sustain these in complex political contexts. Cundill et al. (2015) emphasize the influence of power relationships as TD communities of practice merge. Palmer et al. (2015) reflect on TD practice principles, and Palmer and Munnik (2018) emphasize that, of these, "managing discontinuities" is critical, where discontinuities are the inevitable, unexpected changes in the social-ecological research context. Cockburn and Cundill (2018) alert TD researchers to the underrecognized importance of research ethics in TD practice, and Odume and De Wet (2016) explore the possibility of a relational system of values becoming evident in a TD research context.

We use values as in the VSTEEP (values, and social, technical, ecological, economic, and political context) process of Rogers and Luton (2011), where values provide a reference point as

${ }^{1}$ Institute for Water Research, Rhodes University, Makhanda/Grahamstown, South Africa, ${ }^{2}$ Environmental Learning Research Centre, Department of Education, Rhodes University, Makhanda/Grahamstown, South Africa, ${ }^{3}$ Department of Anthropology, Rhodes University, Makhanda/ Grahamstown, South Africa, ${ }^{4}$ Community Engagement Division, Rhodes University, Makhanda/Grahamstown, South Africa, ${ }^{5}$ Agricultural Research Council - Animal Production Institute, Makhanda/Grahamstown, South Africa, ${ }^{6}$ Dundalk Institute of Technology, Centre for Freshwater and Environmental Studies, Dundalk, Republic of Ireland, ${ }^{7}$ Department of Environmental Science, Rhodes University, Makhanda/Grahamstown, South Africa, ${ }^{8}$ Unilever Centre for Environmental Water Quality, Institute for Water Research, Rhodes University, Makhanda/Grahamstown, South Africa 
Fig. 1. Case studies discussed in this paper. The map shows the location of each of the places discussed in each case study.

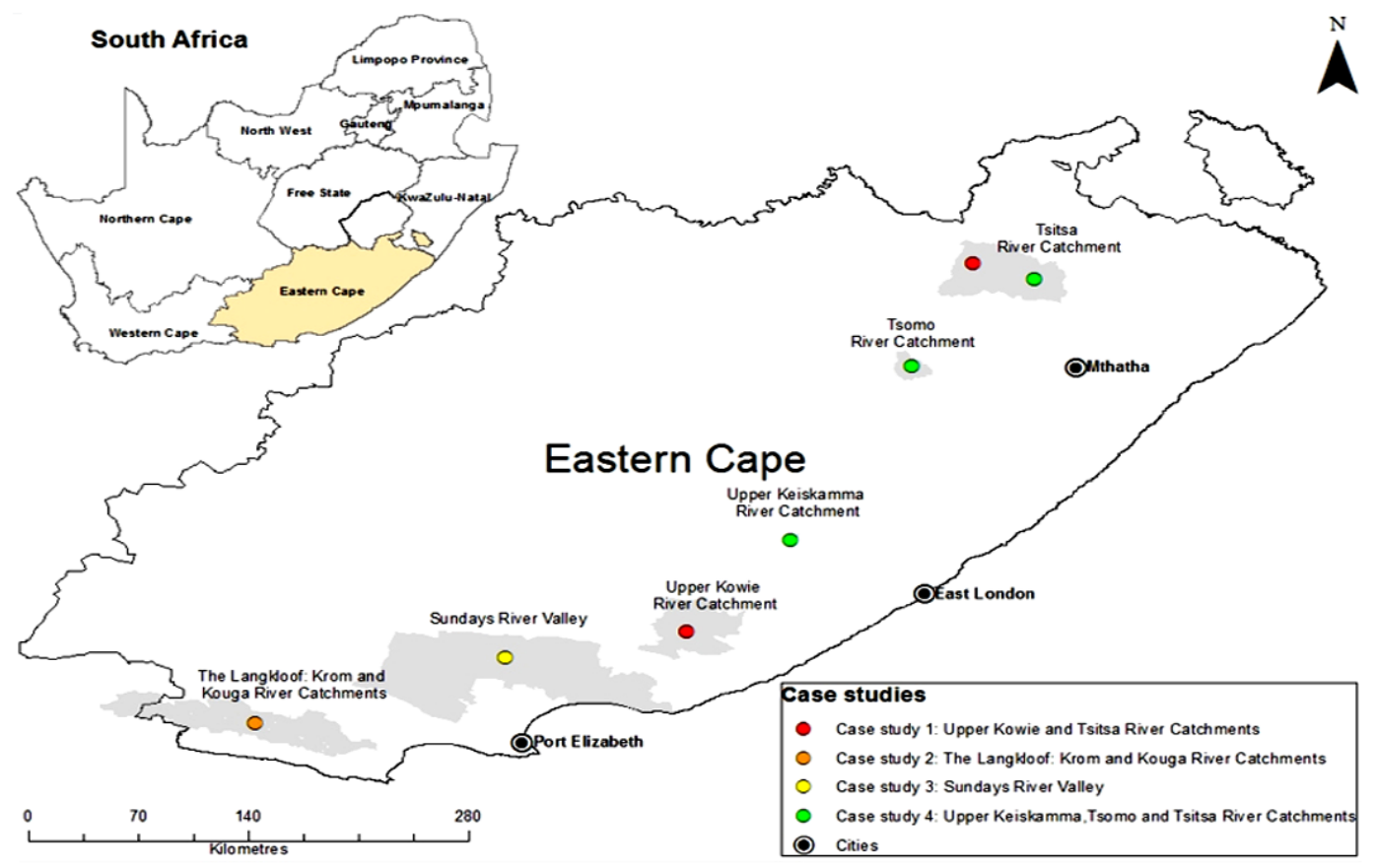

adaptive processes unfold. We understand ethics as reified values. There are various aspects of ethics that relate to TD research: research ethics (Williamson and Prosser 2002), place-based-ethics (Till 2012, Cundill et al. 2017), and human-earth ethics (Chapin et al. 2011). We are interested in the ethics of relationality between people and planet, where social justice, for example, indicated by a reduced Gini index (Catalano et al. 2009), enables a societal consideration of ecological justice, and where people modify their behavior toward long-term ecological sustainability. We will reflect on ethics and values in the case study research presented, probing for TD research practice that could accelerate the realization of sustainable and just natural resource management (NRM).

As they are globally, land and water are justice issues in South Africa. Here, waves of colonization excluded native peoples from their land, culminating in apartheid laws where only white people could legitimately own land. Under these laws, access to water was linked to land ownership, and land owners had exclusive rights to the use of surface and ground water through the riparian principle. Following democracy in 1994, the landmark 1998 National Water Act was promulgated. It was founded on the principles of equity, sustainability, and efficiency, and entrenched a legal right to water for aquatic ecosystems, a global first (Palmer 1999). However, law enables, but does not secure, justice. Achieving fair and just water access in South African landscapes has been fraught with difficulties (Schreiner 2013, CliffordHolmes et al. 2016, 2018), land reform even more so (Jankielsohn and Duvenhage 2017). The result is a complex political-ecological history that sets path-dependencies for any TD sustainability science research.
Although South Africa has a wealth of natural resources, the country faces multiple interconnected sustainability challenges, and the economy is unsustainably resource intensive (Department of Environmental Affairs 2012, Government of South Africa 2012). At the national level there is growing recognition of the challenges of managing the food-water-energy nexus (Von Bormann and Gulati 2014) and the urgency of addressing growing inequality and poverty while working toward environmental sustainability and resilience to future shocks (Government of South Africa 2012).

In this paper, we present four TD research case studies undertaken independently in the Eastern Cape Province, South Africa (Fig. 1). Clifford-Holmes (2015) provides an historical analysis of land and water issues in the Eastern Cape (1814-2011) that informs all the case studies presented. The Eastern Cape, demarcated in 1994, is currently one of the poorest provinces in South Africa (Hebinck et al. 2011). It covers an area of close to $169,000 \mathrm{~km}^{2}(13.9 \%$ of SA's land area) and is the second largest province in South Africa (Statistics South Africa 2012). The province is predominantly rural and encompasses two former homelands (Bantustans), the Transkei and the Ciskei (Hebinck et al. 2011). IsiXhosa is the most widely spoken mother tongue in the province, followed by Afrikaans and English (Statistics South Africa 2012). Most of the income in its rural areas is made up of welfare transfers, and employment rates can be as low as $15 \%$ (Westaway 2012). Many parts of the province lack basic services such as education facilities, health, water, and sanitation. In contrast to its socioeconomic state, the Eastern Cape is rich in biodiversity; it includes all the country's biomes (Hamann and Tuinder 2012), and two global biodiversity hotspots. However, this landscape is 
Table 1. Lang et al. (2012) principles and the interpretation used in the case studies.

\begin{tabular}{|c|c|}
\hline Lang et al. 2012 principle & Interpretation in our case studies \\
\hline Principle 1: Phase A & Identify relevant and interested stakeholders; agree on the societal problem to be researched and \\
\hline Build a collaborative research team & $\begin{array}{l}\text { how to frame and bound it (conceptually, methodologically, geographically; see Audouin et al. } \\
2013 \text { ); clarify roles played by stakeholders. In our studies, this process was mostly led or facilitated } \\
\text { by researchers. }\end{array}$ \\
\hline Principle 2: Phase B & Conduct research collaboratively and within a participatory space; recognize different knowledge \\
\hline $\begin{array}{l}\text { Produce cocreated, solution-oriented, transferable } \\
\text { knowledge }\end{array}$ & $\begin{array}{l}\text { types and perspectives; work toward developing knowledge that can be implemented to address } \\
\text { the societal problem identified in Phase A. }\end{array}$ \\
\hline Principle 3: Phase C & Implement action; make decisions and communicate research based on knowledge cocreated \\
\hline Effect integrated implementation & $\begin{array}{l}\text { during Phase B, both in the societal or practical domain, and in the scientific or academic } \\
\text { domain. }\end{array}$ \\
\hline Principle 4: Cross-cutting & Ongoing and flexible evaluation, reflexivity, and learning that feeds back into project decision \\
\hline Cross-cutting activities: Evaluate adaptively, & making in an iterative manner; active and explicit management of potential conflict among \\
\hline mitigate conflict, and enhance participation & $\begin{array}{l}\text { diverse stakeholders with different worldviews, values, needs, and interests; purposeful facilitation } \\
\text { of participatory spaces that enhance participation in the entire research process. }\end{array}$ \\
\hline
\end{tabular}

confronted with major environmental threats, such as land degradation and water scarcity (Shackleton et al. 2001, Rasch et al. 2017). There are expansive communally owned areas, and many governance-challenged municipalities (Clifford-Holmes et al. 2018). Our focus here is on sustainability challenges in small towns and rural landscapes of the Eastern Cape where natural resources such as land, water, and biodiversity play an important role in local economies and human well-being. In this context, sustainable NRM needs to contribute to the development of inclusive and integrated rural livelihoods and economies that strive toward sustainable and just use of resources from an economic, environmental, and social perspective, for current and future generations (Government of South Africa 2012).

Sustainable and just natural resource management is natural resource management conducted in a manner that recognizes the interconnectedness of social and ecological systems. It therefore works toward interlinked outcomes that benefits the socialecological system as a whole. Such outcomes can be achieved through sustainable management and protection of natural systems, in ways that ensure equitable access to the benefits of natural resources. Furthermore, facilitation of processes and spaces for knowledge production and exchange, and management and governance of natural resources, should be guided by principles of justice, fairness, and democracy (drawing on Agyeman et al. 2003, Ribot 2006 and George and Reed 2017).

Across the Eastern Cape landscapes, we have used a TD approach to engage independently with social-ecological challenges in four case studies: Case Study 1: how to draw stakeholders into fair, effective, participatory water governance; Case Study 2: how to build collaboration among different resource users so as to move toward sustainable landscape management; Case Study 3: how to address inequality in water access in a small municipality; and Case Study 4: how to move toward ecological sustainability in communally owned landscapes (Fig. 1).

\section{METHODOLOGY}

The study employs a multicase study design. Case study research is well suited to research that seeks a situated understanding of real-life contexts and that asks "why?" or "how?" questions (Yin 2009). We used the four cases in an integrated, comparative manner to reflect on the practice of TD research. Although all the cases drew broadly on transdisciplinarity, some were intentionally designed as TD research from the start (Case Studies 2 and 3), and in others, TD practice was more emergent (Case Studies 1 and 4). To conduct a systematic, consistent analysis across the diversity of cases, we retrospectively investigated the application of the Lang et al. (2012) principles across the four case studies (Table 1). Furthermore, case study authors reflected on their cases to explicate their interpretation of sustainable and just NRM, asking how TD research contributed to sustainable and just NRM in their case, and highlighting evidence of ethics and values in the cases.

The methodology for the study was underpinned by our commitment to reflexivity, which informed the research design and analysis. We drew on Popa et al.'s (2015) definition of reflexivity as "a collaborative process of acknowledgment, critical deliberation and mutual learning on values, assumptions and understandings" that enables the generation of "new meanings, new heuristics, and new stakeholder identities" (Popa et al. 2015:47 drawing on Lenoble and Maesschalck 2010).

Although all of us practiced reflexivity within the case research, the development of this comparative study and the paper writing was an opportunity for us to practice reflexivity collectively across the cases. This reflexivity helped us to learn together in a community of practice about the challenges of TD research (Cundill et al. 2015), to reflect critically on underlying values and assumptions, and to grapple with some of the ethical and sociopolitical challenges of engaged research (Cockburn and Cundill 2018). Writing the paper together became a complex and messy TD process itself, in which we learned the importance of careful listening, experienced surprises and a-ha moments, had to manage discontinuities and power dynamics, and at times experienced tensions and discomfort, echoing TD principles developed by Palmer et al. (2007, 2015). We have been working as a collective, with some variation and discontinuities in participants, reflecting on TD practice for approximately seven years. Through this we have developed a shared understanding of TD as not only a way of being in the world and of interacting with one another, but also as a commitment to specific ways of conducting research across disciplinary boundaries and with stakeholders beyond academia (Rhodes University Transdisciplinary Research Group 
2016). We appreciate the importance of reflecting on our positionality, and also on the nature of our interactions with stakeholders in the complex social-political context of South Africa (Box 1).

Box 1: Reflections on researcher positionality and meaningful stakeholder participation.

As part of our reflections on putting TD into practice, we acknowledge that our position in the research matters (Cheng and Randall-Parker 2017), as do power dynamics among participants (Cundill et al. 2015). We recognize that in all our cases, researchers were driving and facilitating the process, and other stakeholders were participants. Although we explicitly sought to address the power dynamic that arises from this situation, we nonetheless acknowledge that researcher-participant relationships cannot be equal. Furthermore, we are cognizant of the importance of diversity in TD teams. This is particularly important in a country like South Africa in which social-cultural diversity and social cohesion, particularly between different race groups, are a societal challenge (Seekings 2008). As an emergent property of being based at a university in the Eastern Cape in South Africa, our TD teams were composed of a diversity of participants, representing various mixes of ages, research experience (both early-career and experienced TD researchers), foundational disciplines, genders, races, and nationalities.

In our engagements with stakeholders we were aware of potential language differences. We worked with experienced translators where necessary and attempted as much as possible to converse directly in local languages, depending on language capabilities in the team (many of us speak isiXhosa and/or Afrikaans as a first, second, or third languages). Our teams were funded by a variety of sources and allowances were made for the flexible, TD nature of research interactions with stakeholders.

The level of participation of stakeholders in the TD processes varied across cases. Although we acknowledge that in many of our cases (particularly those that included time-constrained postgraduate research) full and equitable participation and knowledge cocreation was not possible, we endeavored to facilitate open and participatory processes, and participants were treated with dignity and respect. We believe that our embodying TD principles in these processes created potential for more equitable and meaningful interactions than we have observed in more conventional research processes that focus on extracting information from participants for the sole benefit of researchers (Pain and Francis 2003). We did not conduct a formal evaluation of participants' perceptions of the value of the experiences to them. Nonetheless, through ongoing and open relationships with many of the participants in our cases, and through codeveloping research that addresses societally relevant problems, it appears that the TD research processes have mostly been perceived as beneficial by participants. We are open about the fact that this paper is necessarily a one-sided and personal, researcher-based perspective of the research processes we report on: it is not intended as anything other than that.

\section{CASE STUDIES}

Each case is described briefly for specific context, and to highlight specific historical and political path-dependencies. We apply specific interpretations of the Lang et al. (2012) principles to these four case studies (Table 1).

\section{Case Study 1: Upper Kowie and Tsitsa River Catchments}

This case study explores participatory water governance processes within public forums in two catchments (Upper Kowie River and Tsitsa River) in the Eastern Cape. This case highlights the potential role of learning in TD research.

The Makana Local Municipality, including the urban center Grahamstown/Makhanda, is located in the drought-prone Upper Kowie River catchment. The complex array of interdependent water challenges includes high unemployment and socioeconomic inequity; increasing population (Statistics South Africa 2012); aged and poorly maintained water-related infrastructure; polluted rivers (particularly related to poorly functioning waste water treatment works); local dams inadequate for water supply; domestic water supply augmented by an interbasin transfer but inadequate water treatment capacity; little appreciation of the link between the catchment and water supply; and municipal governance dysfunction (Weaver et. al. 2017, Palmer and Munnik 2018). In the Makana Local Municipality context with its array of water challenges, a local water forum emerged.

The Tsitsa River catchment includes three small towns, many villages, and mainly communally owned land. Municipal and traditional authority governance is concurrent. As in many rural municipalities, water service delivery is poor (Elundini Municipality 2016). Rural populations are declining (Statistics South Africa 2012), and subsistence agriculture is still a core livelihood activity. Livestock production is linked to landscape degradation (Bennett and Barrett 2007, Sandhage-Hofmann et al. 2015, Reed et al. 2015), and historical rain-fed agriculture has been abandoned (deagrarianization) in many places in the landscape, in part as a result of decreasing annual rainfall patterns. However, the area has the capacity to support household rainfall harvesting and vegetable production (Sisitka et al. 2016). The catchment is the site for a large government landscape restoration program with embedded CSES research that includes the development of local participatory governance capacity (Powell et al. 2018).

\section{Case Study 2: The Langkloof: Krom and Kouga River \\ Catchments}

In this case study, a transdisciplinary participatory space was created by the researcher (a doctoral candidate) partnering with a nongovernment organization Living Lands (Living Lands 2017), in a knowledge coproduction process to gain a better understanding of environmental stewardship and multistakeholder collaboration in the Langkloof (Cockburn 2018). The Langkloof falls within the Kouga and Krom River catchments, which together provide almost $70 \%$ of the water for the city of Port Elizabeth. The area has high biodiversity value, which is under threat from invasive alien plants and unsustainable farming practices (Mander et al. 2010, McClure 2012). In addition, the area faces significant social challenges, including high levels of inequality, conflicts around access to land and water, and a lack of social cohesion (de Laat 2017). The landscape is valued for agriculture, conservation, tourism, water production, and as a 
home for many people. Thus, multistakeholder collaboration is necessary for the sustainable and just management of the landscape.

\section{Case Study 3: The Sundays River Valley}

Twenty years into a new political dispensation, many South Africans still experience insecurity of water supply in their homes (Molony 2014, Hamer et al. 2018). This is often the result of secondary scarcity, where there is sufficient water locally, but there are governance and/or infrastructural barriers constraining water supply. In this case study, we used an explicitly transdisciplinary approach to explore domestic water supply in the Lower Sundays River Valley Municipality (Clifford-Holmes 2015).

The key contextual factors relate to postapartheid policy, legislation, governance, and institutional arrangements. In South Africa, integrated water resource management (IWRM) and water supply are governed by different laws and implemented through a variety of institutions. The National Water Act governs integrated water resource management and specifies statutory institutions such as Catchment Management Agencies, which are responsible for integrated water resource management, and Water User Associations which, historically, supplied irrigation water, and after democracy, took on the additional responsibility of supplying local municipalities. Catchment Management Forums are identified as nonstatutory institutions for civil society participation. Local municipalities are governed by several pieces of legislation, including the Water Services Act, and may act as a water service authority (with oversight), and/or the water service provider (with supply obligations). There is no primary water scarcity in the Lower Sundays River Valley Municipality area: water is supplied by interbasin water transfer, with infrastructure built to secure irrigation water for the local export citrus industry.

\section{Case Study 4: Tsitsa, Upper Keiskamma, and Tsomo River Catchments}

This case study is set in three catchments in the Eastern Cape: in a different part of the Tsitsa River, Upper Keiskamma, and Tsomo River catchments. The three catchments have high rates of unemployment, poverty and the majority of the people are dependent on social grants (Statistics South Africa 2012).

\section{Tsitsa River catchment}

Within this catchment, rural communities rely heavily on natural resources and practice subsistence farming, which includes both livestock and crop production (van Tol et al. 2016). The hillslope seep wetlands supply biomass for grazing, particularly in late winter, serving as important ecological infrastructure. Overgrazing is an issue, with $70 \%$ of the catchment area under communal land tenure characterized by poor land management practices (ERS 2011).

\section{Upper Keiskamma River catchment}

The study sites selected in the Upper Keiskamma River catchment are located in a semiarid region that is characterized by coastal grassland and savanna in the coastal areas, valley thicket in the river valley, and indigenous forest up the mountains (Mucina and Rutherford 2006). Communal lands in this catchment are used for livestock grazing and minimal dry land cultivation (van Tol et al. 2016). Because of the collapse of livestock and rangeland management structures that were employed through the betterment planning system of the apartheid government, the quality of the communal lands in this catchment has deteriorated and there is a prevalence of overgrazed and eroded lands (Palmer and Bennett 2013).

\section{Tsomo River catchment}

The communal lands in this catchment have been utilized by livestock for many years. The rangelands utilized by livestock are perceived to be unproductive and degraded because of extensive agriculture and livestock farming in the past (Perret et al. 2000, Palmer and Ainslie 2006).

Within these three catchments, ecosystem health has become a concern for livestock owners and subsistence farmers, especially in areas where there are no governance structures to facilitate effective collective management of communal natural resources. These include rangelands that provide goods and services, such as grazing for livestock (Shackleton et al. 2007, Reid et al. 2008). This case study, therefore, sought to understand social and ecological interactions in order to find effective and sustainable solutions for the improvement of NRM in communal grazing/ livestock systems.

\section{RESULTS}

The diverse and contextualized interpretations and experiences of applying TD research design principles (Lang et al. 2012) in our four case studies is described in detail in Table 2. Our casespecific interpretation of sustainable and just NRM, and evidence of our experiences of working with ethics and values in our case studies are presented in Table 3 . We urge readers to initially engage with the information presented in the tables. In the following text we then provide a brief synthesis of key insights.

Retrospective analysis of the case studies allowed us to acknowledge the challenges of building research teams (Principle 1: Phase A). In most cases teams were built in response to university-led research. Regardless of team-building processes and stakeholders represented, all four case studies demonstrated the importance of reflexivity and trust for integrated implementation of diverse perspectives and enhancing participation. As the Upper Keiskamma, Tsomo, and Tsitsa River catchments case study shows, researchers and teams need to select engagement methods that could accommodate epistemic equality, legitimize different knowledge holders, and acknowledge different power relationships. These selected engagement methods require more than simply opening space for participation. Rather, they call for actively facilitating spaces for enhanced participation and explicit reflection, striving to take outcomes of such enhanced participation further into decision-making processes influencing NRM.

Although research questions may have changed as the research teams built relationships with stakeholders, generally, societal problems were assumed and questions were designed and conceptualized initially by the research project. This preconceived notion of societal problems is a potential drawback of universityled TD research processes. The exception to this was the Langkloof case study, where the researcher's broad questions changed as relationships between the researcher and local partners became more established, facilitating the emergence of a collective understanding of societal problems.

A variety of methods including workshops, focus groups, adaptive planning, interviews, and participatory mapping were used across 
Table 2. Design principles, interpretation, and application in each case study.

Principle from Lang et al. (2012)

Interpretation of the principle in the study as a whole

Principle 1: Phase A

Build a collaborative research team

Identify relevant and interested stakeholders; agree on the societal problem to be researched and how to frame and bound it (conceptually, methodologically, geographically; see Audouin et al. 2013); clarify roles played by stakeholders. In our studies, this process was mostly led or facilitated by researchers.

\section{Case Studies}

Application and interpretation of the principles per case study

Case Study 1: Upper Kowie and Tsitsa River Catchments (2015-ongoing)

Team: The team emerged from an existing University-based transdisciplinary (TD) research group, composed of staff (senior and early career researchers) and postgraduate students (one doctoral and two Master's students) from different disciplines (ecology, environmental education, and environmental health).

A cocreated understanding of TD research practice emerged from reflexive engagement with disciplinary and transdisciplinary literature in the context of active projects.

Societal problem: Two key factors continue to influence inequality in participatory water governance processes and were confirmed by the research in this case: power imbalances, and lack of sufficient knowledge in relation to water laws and institutional arrangements by civil society representatives, particularly in rural areas. As such, the voices and needs of civil society remain unheard in natural resource management decision-making processes.

Frame and bound: The team actively used TD research principles from Palmer et al. (2015): equality of voice among participants mixing early career and experienced researchers; learning by doing (playing), and articulating clearly the added value of wide-ranging discourses (Palmer and Munnik 2018).

The workshops included interactive knowledge-sharing sessions between participants and researcher teams. Open and engaged knowledge exchange supported the emergence of consensus on the constellation of key issues.

Case Study 2: The Langkloof: Krom and Kouga River Catchments (2015-2017)

Team: A new team was not built from scratch, but rather the researcher (a doctoral candidate) joined an existing team as an embedded researcher within the local NGO project team (Vindrola-Padros et al. 2017). Identifying and building relationships within a transdisciplinary epistemic community (as was done in this study by partnering with a local NGO) is considered an important enabler of individual TD practice and knowledge coproduction (van Breda et al. 2016).

Societal problem: The Langkloof is a multifunctional rural landscape in which a variety of stakeholders have different interests. The NGO partner (Living Lands) works toward a vision of "collaborations on living landscapes." They aim to bring stakeholders together to manage the landscape in a more integrated manner for long-term sustainability.

The societal problem is thus how to bring diverse and conflicting stakeholders together across the landscape, and how to manage biodiversity, water, agriculture, and rural development interests in a mutually beneficial and integrated way.

Frame and bound: The researcher had an initial broad idea for research questions. However, through participating in the NGO's activities and discussions, these were refined, and a final set of more specific research objectives, a methodological framework, and a shared understanding of the focal area of the research were agreed upon approximately one year after initial engagement. The more focused research question became, "How do we build collaboration for sustainable landscape management between multiple stakeholders in the landscape?" This lengthy process reiterates the importance of a preparatory phase of relationshipbuilding and explicating shared values before research questions and methodologies can be developed (Cockburn et al. 2016).

Case Study 3. The Sundays River Valley (2011-2013)

Team: We opportunistically built a research team from within a funding opportunity, seeking researchers open to TD and systemic approaches. The team mixed experienced and emerging researchers. Relevant and interested stakeholders were identified and engaged, and together framed the societal problem of water in the Lower Sundays River Valley Municipality. Most research processes were led or facilitated by researchers.

The primary stakeholder research collaboration emerged from an existing relationship between the university and the local water board. Water supply responsibilities were delegated to the Amatola Water Board and their research partnership with Rhodes University was activated. This engaged, transdisciplinary, action research included a strong process of coproduction of knowledge with stakeholders.

Societal problem: Twenty years into a new political dispensation, many South Africans still experience insecurity of water supply in their homes (Molony 2014, Hamer et al. 2018). This insecurity is mainly the result of secondary scarcity, where there is sufficient water locally, but there are governance and/or infrastructural barriers constraining water supply. 
Principle 2: Phase B

Produce cocreated, solution-oriented, transferable knowledge

Conduct research collaboratively and within a participatory space; recognize different knowledge types and perspectives; work toward developing knowledge that can be implemented to address the societal problem identified in Phase A.
Frame and bound: A specified objective was to assemble a team with a range of disciplinary skills, a commitment to a transdisciplinary approach, and willingness to embrace the concepts of complex socialecological systems (CSES; Folke 2006), resilience (Biggs et al. 2012), and critical complexity theory (Preiser et al. 2013).

Case Study 4: Upper Keiskamma, Tsomo, and Tsitsa River Catchments (2015-ongoing) Team: Local community members were invited to participate in focus group discussions, participatory mapping exercises, and interviews concerning livestock and rangeland management. Participation varied between the three catchments presented in this case. Based on consistency in participation of the community members, a loosely convened team emerged, consisting of the researchers, community livestock owners, and representatives of the traditional council.

Societal problem: Management of natural resources in communally owned landscapes is complex (Ainslie and Kepe 2002). This complex management is especially true in areas where rangelands are open access, and livestock owners do not have governance structures that allow them to effectively manage their natural resources collectively. As a result, the ecosystem health of these natural resources (rangelands and wetlands), and the potential socioeconomic and livelihood implications thereof have become a concern.

Frame and bound: A social-ecological systems framing helped to ensure integration of natural and social sciences, to elicit knowledge from different actors in order to understand people's perceptions concerning rangelands (using focus group discussions, surveys, and participatory mapping) and the extent of actual rangeland degradation (using Veld Condition Assessment, Floristic Quality Assessment Index, and Wetland Index Value).

Case Study 1: Upper Kowie and Tsitsa River Catchments

Workshops, with regular reflection and learning opportunities, were used to cocreate solution-oriented and transferable knowledge. Researchers identified tensions and concerns in written and recorded material and used these in feedback sessions as discussion points for learning and cocreation of solutions (Wolff 2019). Adaptive planning workshops integrated inputs from different stakeholders to develop integrated, possible, transferrable solutions for each of the study catchments (Rogers and Luton 2011, Lang et al. 2012). The workshop process was designed to make previously inaccessible knowledge, such as technocratic water system information and data, water-related legislation, and water user-specific knowledge, such as traditional healer practices, accessible to diverse stakeholders. Information was presented in layperson's terms and made more accessible through language translation, maps, photographs, and graphics.

Case Study 2: The Langkloof: Krom and Kouga River Catchments

Knowledge in this research project was created through two data-generation activities: (i) participant observation by the embedded researcher during the NGO activities, and (ii) interviews with stakeholders in the landscape about environmental stewardship and collaboration. The primary data were gathered by the researcher; however, frequent and ongoing research feedback discussions and email exchanges with the NGO team meant that the NGO team's knowledge and understanding were also woven into the overall knowledge generated. This process ensured that the knowledge generated was solution-oriented because it was based on a key challenge faced by the NGO, articulated in the research questions. The knowledge was transferrable because it was developed through an iterative process of discussion, engagement, and reflection with the NGO team. Thus, the usual linear distance across which knowledge must be transferred, i.e., from "knowledge producer" to "knowledge user" (van Kerkhoff and Lebel 2006), was shortened.

Case Study 3. The Sundays River Valley

A water supply systems analysis was codeveloped with the Water User Association and the Lower Sundays River Valley Municipality (Clifford-Holmes et al. 2018), and the systemic approach subsequently transferred and implemented in the Olifants River catchment (AWARD 2017). Water supply responsibilities were delegated to the Amatola Water Board and their research partnership with Rhodes University was activated. Engaged, transdisciplinary, action research aimed to loosen the wicked water supply problem (sensu Rittel and Webber 1973) through cocreated knowledge with stakeholders, empowered action and mobility, and reflectiondriven insight. Knowledge from residents was elicited, analyzed, and mirrored back through translated presentations and documentation. The results are being used in a private sector partnership to produce household water storage and transport containers of preferred size and affordable price. The waste water treatment works study involved cooperation in improving the performance evaluation of the works (Muller 2013), which was subsequently achieved and maintained.

Case Study 4: Upper Keiskamma, Tsomo, and Tsitsa River Catchments Focus group discussions, surveys, and participatory mapping were used to engage stakeholders in the cocreation of a common knowledge basis about wetland sustainability, grazing management, and interactions between people and their livestock. In the discussions, a joint understanding of issues emerged from both community members and researchers, about, for example, the lack of service provision from the agricultural extension offices, climatic factors including drought and rainfall variability, soil erosion, and increased invasion by alien plants. 
Principle 3: Phase C

Effect integrated implementation

Implement action; make decisions and communicate research based on knowledge cocreated during Phase B, both in the societal or practical domain, and in the scientific or academic domain.
Principle 4: Cross-cutting

Cross-cutting activities: Evaluate adaptively, mitigate conflict, and enhance participation

Ongoing and flexible evaluation, reflexivity and learning that feeds back into project decision making in an iterative manner; active and explicit management of potential conflict among diverse stakeholders with different worldviews, values, needs, and interests; purposeful facilitation of participatory spaces that enhance participation in the entire research process.

Case Study 1: Upper Kowie and Tsitsa River Catchments

Codeveloped solutions that emerged from the reflection and learning sessions were implemented in practice by participating decision makers. For example, a multistakeholder water-learning journey around Makana Municipality, with learning exchange stops, was commended by the Municipality, and will be repeated regularly. In the Tsitsa River catchment two national government departments are actively engaging on issues raised by the community through the research project.

Case Study 2: The Langkloof: Krom and Kouga River Catchments

One of the tangible forms of cocreated knowledge was a map of social subcommunities in the landscape, which is being used by the NGO to support more inclusive and socially just stakeholder engagement. Another key finding of the research was the elucidation of significant social-relational barriers to collaboration. This finding has provided renewed impetus for the NGO to focus on long-term, meaningful relationship-building as a priority.

Case Study 3. The Sundays River Valley

The Water Users Association and the Lower Sundays River Valley Municipality verbally agreed to reduce water supply interruptions; but inadequate large-scale water storage infrastructure, waste water treatment works upgrade, effective financial management, and signing a service-level agreement were identified as vital advances, but were not achieved within the project time frame.

Case Study 4: Upper Keiskamma, Tsomo, and Tsitsa River Catchments

Although all catchments (Upper Keiskamma, Tsomo, and Tsitsa) in this case were not at an implementation stage, household interviews and focus group discussions revealed that an awareness had developed of the extent and effects of rangeland and wetland degradation.

Case Study 1: Upper Kowie and Tsitsa River Catchments

Careful and considered facilitation of workshops and feedback sessions supported relationship and trust building (Palmer et al. 2018). In these safe participatory spaces the facilitators worked to ensure that all voices were heard and that planned activities allowed for reflection, flexibility, and adaptation.

Conflict was mitigated by acknowledging stakeholder diversity and agreeing on principles of engagement, e.g., respecting different viewpoints, and seeking to understand others before seeking to be understood.

Case Study 2: The Langkloof: Krom and Kouga River Catchments

The researcher's role in the team was clearly defined to ensure a shared understanding of how much participation was required from both parties, and how potential conflict would be managed. One weakness of this TD research team was that it did not have a wide range of disciplines represented and did not include resource users directly. This weakness illustrates the challenges of working opportunistically in partnering societal actors who are open to participating in a knowledge coproduction process, as opposed to designing the ideal TD team, e.g., by including resource users / landscape residents, to suit a particular societal problem or question.

Although the Lang et al. (2012) design principles were not applied explicitly in this project, ongoing communication and collective reflections throughout the knowledge coproduction process was a form of implicit evaluation and learning by doing.

Case Study 3. The Sundays River Valley

Activities were adaptive, specifically in flexible timing and judicious repetition of content and progress when local government and civil society participants change regularly. Evaluation was informal and reflexive, and a potential weakness of the design. Conflict mitigation is inherent in the strategic adaptive management process of Rogers and Luton (2011), by actively encouraging consensus development, rather than seeking compromise.

Case Study 4: Upper Keiskamma, Tsomo, and Tsitsa River Catchments

Key people in the community, including community leaders such as traditional leaders (chiefs), or ward councilors, and trusted members of the community, were engaged prior to meetings with the community members. This engagement was an important step toward gaining people's trust and commitment in subsequent meetings with the wider communities where research objectives were explained and people given a chance to respond and contribute. In platforms such as focus group discussions with different stakeholders, the emergence of power dynamics is inevitable. In this case, discussions were held in such a way that people's different opinions were equally considered and noted, potentially reducing conflict and creating consensusbased solutions.

the case studies to elicit knowledge and deepen understanding of held knowledge and shared understanding between researchers and participants (Principle 2: Phase B and Principle 4: Crosscutting). Technical matters (Upper Kowie and Tsitsa River and Sundays River Valley case studies) were presented through translated presentations, maps, and graphics. Careful, respectful listening and speaking encouraged common and shared understanding of each other's points of view, and the problems being discussed. Humility and respect on the part of researchers were important to acknowledge indigenous and local knowledge and incorporate this knowledge into the research process. In each of the case studies, the researchers used participatory spaces to feedback and reflect on shared understanding and information.

The case studies highlight the challenge of implementing integrated knowledge (Principle 3: Phase C) and solutions, even in longer term projects. We noted the time required to form a 
Table 3. Interpretation of "sustainable and just" evidence of ethics and values.

Understanding of "sustainable and Case Study 1: Upper Kowie and Tsitsa River Catchments

just" in each case
Sustainable natural resource management (NRM) was interpreted at two levels: first, the case sought to promote the sustainability of sufficient clean water for people and the environment now and in the future; and second, contribute to the resource-related sustainability through influencing forums as institutions conducive to ongoing public participation in NRM process.

Just NRM was interpreted at the primary level of fair distribution and access to clean water for people and the environment, and at a secondary level, as the enabling environment for fair participation in forums and the capacity of people to engage in NRM decision making on an even footing.

Case Study 2: The Langkloof: Krom and Kouga River Catchments

Sustainable NRM in this case is understood as an integrated set of management activities occurring across the landscape, which contribute to improved ecological functioning, now and for future generations. For example, this includes sustainable farming practices, restoration of riparian areas and wetlands, and sustainable harvesting of wild honeybush tea.

The understanding of just NRM in this case means that inequalities in resource benefits between different stakeholders are recognized, and steps are taken to address them. For example, most land and water access currently lies in the hands of commercial white farmers, and land and water restitution processes (led by government) are underway to better share access to these resources among the diverse residents of the Langkloof.

The NGO is working toward sustainable and just NRM by facilitating multistakeholder collaboration across the landscape toward more integrated management of the landscape for the benefit of all residents. They employ local "landscape mobilizers" to build meaningful relationships with diverse stakeholders and cocreate project activities on the landscape (See NGO report: Living Lands 2017 and Cockburn 2018).

Case Study 3. The Sundays River Valley

The South African context of water injustice drove a rapid escalation of water supply demand, accompanied by governance and infrastructural challenges in the postdemocracy years (Clifford-Holmes et al. 2016). Sustainability is also a justice issue, and includes securing a viable social-ecological future (Swilling and Annecke 2012). Water is a justice and sustainability issue (Rockström et al. 2009) because water resources in the landscape support water supply for human use and in South Africa, there are substantive risks to the whole natural, infrastructural, and governance water system (Palmer and Munnik 2018). The question investigated by the researchers focused on the disjunct between the water scarcity experience by people in the Lower Sundays River Municipality, and the thriving, irrigated citrus industry. The aim of the Lower Sundays River Valley Municipality case study was to facilitate the codevelopment of a more evenly shared understanding of the whole Lower Sundays River Valley Municipality water system, and to support a transition to a more equitable water supply to all residents, in the context of the natural water resource.

Case Study 4: Upper Keiskamma, Tsomo, and Tsitsa River Catchments

The case study sites are located in the former homelands (Bantustans) that have a history of human displacement from the surrounding area and subsequent concentration into a smaller area, where people were forced to manage and utilize natural resources collectively. Over the years, this has presented challenges to the ecological sustainability of these natural resources because there are people who tend to ignore community rules and exploit the resource without considering long-term degradation (Ostrom 1990). Moreover, post-1994, a decline in agricultural extension services has been noted in the communal sector with negative effects on agricultural production and rural people's livelihoods (Williams et al. 2008). These declining agricultural extension services have implications for sustainable and just NRM.

In this case study, sustainable and just NRM is understood as first, the sustainability of wetlands and rangelands for the improvement of livestock quality and the well-being of rural people whose livelihoods depend on livestock, and second, as establishing or strengthening institutional arrangements and governance structures at community level that would promote good wetland and rangeland management strategies and socially just benefits. Third, an improvement in the provision of agricultural extension services from the Department of Rural Development and Agrarian Reform is needed to achieve sustainable and just NRM.

How the case has attempted to contribute to sustainable and just NRM

\section{Case Study 1: Upper Kowie and Tsitsa River Catchments}

Researchers accepted that the wide diversity of participants came from, and to, different levels of understanding at different times. Careful facilitation of power imbalances created a meeting environment that enabled the sharing of different understandings and perspectives, particularly those often silenced, or voiceless. In this case study, working with different knowledge and understandings, and building relationships over time, allowed the integration of new knowledge (shared concerns among stakeholders) and just decision making toward sustainable solutions to contextually specific complex social-ecological problems.

Case Study 2: The Langkloof: Krom and Kouga River Catchments

Out of a commitment to transdisciplinary (TD) research principles, reflexivity became a key practice in this case.

Consequently, although just NRM was not a key focus of the research at the start, reflexive engagements with the context, stakeholders, and data revealed that inequitable access to natural resources across the landscape was a significant constraint to effective multistakeholder collaboration. In this way, the TD research helped to foreground this issue in an initiative with a strong focus on ecological outcomes and the researcher hopes to have created enabling conditions for sustainable and just NRM from an interlinked social-ecological perspective. 
Evidence of ethics and values in the case
Case Study 3. The Sundays River Valley

At the end of the three-year study (2011-2013) there was a broader understanding of the Lower Sundays River Valley Municipality water system; institutions experienced conflict mitigation and relationship-building; a key governance barrier was identified; there was feedback to the wide community; students graduated and published findings. However, the governance barrier was not formally resolved; local residents experienced minimal improvement in water security; the waste water treatment works' performance improved, but remained poor; and researchers used learning to initiate participatory water governance processes in neighboring municipalities (Palmer and Munnik 2018). The Water User Association (responsible for water delivery to orchards, and to the Lower Sundays River Valley Municipality) and the Lower Sundays River Valley Municipality (responsible for water supply to households) verbally agreed to sign a service-level agreement to improve household water security. However, improved relationships lulled a sense of urgency for formal agreement, and in the face of no easily accessible template, nothing was signed. Improved water security required improved water storage, which required improved financial management and securing appropriate grants. Ultimately, the project achieved a diagnosis, and at best, early steps toward solutions.

Case Study 4: Upper Keiskamma, Tsomo and Tsitsa River Catchments

In this case study, engaging communal farmers in order to give them a voice was the first step toward achieving sustainable and just NRM. There was a general consensus among participants from the different catchments that there is a need to form a rangeland management structure. A formal structure may allow the communities to be represented when there are regional farmers' meetings and they could compile a list of complaints and needs and take them to their local agricultural extension offices. The biological assessment tools were used to assess rangeland and wetland conditions and the knowledge acquired was fed back to community members to inform them of the current status of their rangelands, permitting spaces to develop strategies to improve the sustainability of natural resources in a collective process in which community voice was foregrounded.

\section{Case Study 1: Upper Kowie and Tsitsa River Catchments}

Besides adherence to the university's code of research ethics, a culture of embodied ethical research practice was nurtured within individuals composing the research team through a process of participation and informal reflexivity. Principles of ethical engagement (largely shaped by TD principles developed by Palmer et al. 2007, and built upon by participants) were made explicit early in the research process and reiterated at the outset of subsequent engagement processes, e.g., adaptive planning workshops. The importance of values was foregrounded, particularly in the adaptive planning process where a shared set of values were identified and adopted to guide the future engagement.

Case Study 2: The Langkloof: Krom and Kouga River Catchments

Reflexivity, a key principle of TD (Principle 4), allowed the researcher to recognize the importance of practicing everyday ethics in the absence of formal institutional research ethics procedures when unexpected research ethics challenges arose in the field (Cockburn and Cundill 2018).

Having made a commitment to cocreating the research questions and focus with the practitioner partners (Principle 1), a process of explicating values emerged. From this, shared values were identified around which research questions were coconstructed. Without foregrounding values and expectations in this way, developing a shared commitment to the ongoing research process would have been difficult.

Case Study 3. The Sundays River Valley

The research received university ethical clearance, with specific attention to permissions, anonymity, and reporting results back to stakeholders. Researchers engaged with stakeholders, collectively, using an adaptive planning process that is designed for fair inclusive participation (Rogers and Luton 2011, Palmer et al. 2018). The adaptive planning process includes a step in which participants share their values, and the implications of their shared, diverse value system. Plurality and conflict emerged strongly among case study stakeholders, drawing attention to the frontier of relational and transdisciplinary ethics (Odume and de Wet 2016, Cockburn and Cundill 2018).

Case Study 4: Upper Keiskamma, Tsomo, and Tsitsa River Catchments

University ethical clearances were obtained before conducting the study. A consent form was provided prior to the interviews for all the households and elders in order to request their authorization. Transparency was vital to avoid building false expectations and people had a right to withdraw their participation at any time. Engaging key stakeholders and constantly giving them feedback was important and enhanced participation of the communities in the research. Participants reported that they were more hopeful now because their voices were being considered. coherent team is important, but can be pressurizing if you are a student researcher funded for a specified time frame that does not match the research project goals, the societal problem, or the time required to engage. The pressure on the researcher could mean that true engagement and deep understanding may not happen. This challenge emphasizes the need for values of honesty and integrity and the position of both researcher and participants to be clarified upfront and explicitly. All of the case studies did this.

For the reasons given, integrated implementation (Principle 3) was not always possible. By using the Lang et al. (2012) principles to retrospectively analyze the case studies, we discovered similarities in the way in which we were engaging, often driven by our own personal ethics and values, and in some cases by eliciting values from participants to build trust and common ground. By reflecting among ourselves, we came to appreciate the guidance of our own everyday ethics (Cockburn and Cundill 2018), and the general guiding principles of research ethics provided by the university ethics committee (Cockburn and Cundill 2018) as important when engaging with people and their close relationship with the environment.

Lang et al. (2012) Principle 4 encourages mitigating conflict, facilitating evaluation and enhancing participation. Each case 
study demonstrates aspects of reflection (within the teams) and with participants (feedback workshops). The reflection alerted researchers to explicitly take account of the social-politicalhistorical context in each case and raised awareness as to how these social-political-historical factors influence sustainable and just NRM. By working with diverse stakeholders who had shared their values and knowledge during the engagement processes, coproduced knowledge made the research more robust and meant that the research findings were more likely to find purchase with stakeholders and influence management and governance of the social-ecological system.

The intricate links to pathways of sustainability between values and ethics, and inequity and diversity in the Eastern Cape context required interrogation across case studies. The case studies themselves may not have looked explicitly for values and ethics during their research, but the everyday ethics employed by research teams allowed the emergence of shared values and ways of working together constructively. A TD principles orientation (Palmer et al. 2015) encouraged us to work ethically in a valuesbased way with participants.

\section{DISCUSSION}

There are challenging implications that come with the recognition that social-ecological systems are complex (Swilling and Annecke 2012). One of these is the overriding importance of context, and with a multiplicity of contexts, comes difficulty with generalizations. Transdisciplinary researchers have therefore used principles as their shared points of reference.

Research using the Lang et al. (2012) principles has generated additional practical insights. Polk (2014) identified three assumptions underlying TD research:

- the range of stakeholders provides a diversity of normative positions as a basis for negotiation;

- complexity fundamentally requires a range of methods, approaches, and philosophies;

- and academic with nonacademic involvement gives rigor and relevance.

Although these design principles are useful, they may be too simplistic in that they ignore perceived status differences between disciplines. As Cockburn et al. (2016) points out, specific enabling actions to build and maintain teams are needed to realize the principles in action. Specifically, they argued that social-relational processes need more attention, for example, putting in place enabling organizational preconditions, assembling a functional well-structured team, and actively building interpersonal and individual collaborative capacity. Luthe (2017) also endorsed the principled framing, and suggested six practical factors necessary for success:

- research originating from society;

- readily available funding;

- flexibility in required milestones, methods, and outcomes;

- acceptance of process as a product/result;

- effective public communication;
- and a demand-driven transition to a prolonged or new project partnership.

Several of these perspectives challenge the customary logical framework matrix planning and reporting of conventionally funded research. More philosophically, Van Breda and Swilling (2019) focused on the complex system property of emergence, and, with Rogers and Luton (2011) and Rogers et al. (2013), specifically noted the inevitability of nonlinear and unpredictable research and practice pathways. The flexibility, fluidity, and openmindedness required of TD research means that, in most cases, the research questions formulated at the beginning of the research journey evolve; participants shift and change, and even research directions are adapted through collaborative interactions between researchers (academics) and societal actors. Kingsford and Biggs (2011) highlight adaptive responses; Ison (2010) and Foster et al. (2018) advocate systems thinking, and there is an emerging recognition that learning underpins all responses to complexity (Rogers et al. 2013, Kabogo et al. 2017, Denney et al. 2018).

Our contributions to these emerging threads that are weaving a philosophy, theory, and practice of TD research are (i) to affirm from our practice the suite of insights above, and (ii) to bring to the fore the centrality of values and ethics. Cockburn and Cundill (2018) clearly point out that TD research presents ethical challenges that go beyond the conventional procedural ethics at institutions of higher learning. Given such emergence, conventional procedural ethics that only require ethics approval before the initiation of research are problematic. Our case studies clearly had to grapple with these research ethical challenges with little principled guidance relating specifically to values and ethics (Table 3). Reflecting on our individual and collective experiences, and in line with Cockburn and Cundill (2018), we argue for an everyday ethics or ethics-in-practice (Rossman and Rallis 2010) to pervade TD design principle. The implication of such an everyday ethics is that the researcher has to embody ethical behavior, reflective of formal institutional procedural research ethics and should personally take responsibility for embedding ethical principles at all stages of the research process through reflexivity and relationality (Cockburn and Cundill 2018).

Early in the transdisciplinary literature, Max-Neef (2005) presented a hierarchical, layered heuristic for integration across disciplines (Fig. 2). Values and ethics are at the apex. Drawing on environmental ethics, Odume and De Wet (2016) propose that a systemic-relational ethic is necessary to accommodate diverse social-ecological values, and in terms through which these values can be negotiated in relation to each other. Values held by stakeholders in the case studies came to the fore through participatory TD processes, and through ongoing participation and negotiation, a set of shared values emerged around which the shared TD research practices could coalesce (Table 3). This was done by relying on a set of ethical principles germane to, and emergent from, the CSES context of each of the case studies. Like other investigators (e.g., Pohl and Hadorn 2008, Popa et al. 2015), in the Langkloof, Upper Kowie (Hamer et al. 2018) and Tsitsa case studies, we experienced ethical challenges that went far beyond what conventional procedural research ethics accounted for. 
Fig. 2. A layered concept of transdisciplinarity adapted from Max-Neef (2005), Palmer and Munnik (2018); C. Mitchell, personal communication.

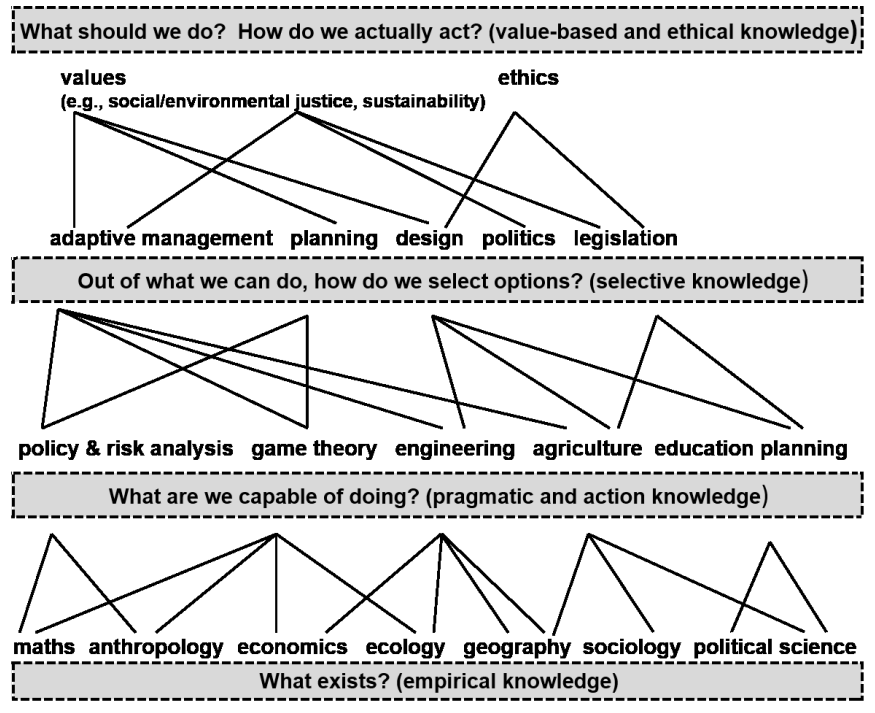

The socially and culturally diverse, and ecologically, economically, and politically unequal society of the Eastern Cape, South Africa, forced attention on values in our TD research. The historical legacies of apartheid laws, particularly those related to access to land and water, meant that participants across all four case studies were not participating on an equal footing within the TD process. Values exercise significant, deciding influence over actions and behavior toward other people, and toward the natural environment. In our cases, a diversity of values was articulated through participatory TD processes. Different values, and different needs and motivations, were held by different stakeholders, and became explicit through the wide range of knowledge types, objectives, and problem framings in each case study. Our experience of grappling with sustainability issues suggests that an ethic founded on a fundamental value of the CSES as a whole, is necessary for transitions toward social and ecological justice.

We therefore argue that the better the ground is prepared, and continuously nourished, i.e., the more attention is paid to explicating and deliberating our values in TD teams within a particular social-ecological systems context, the more likely we are to succeed in conducting TD research toward sustainable and just NRM (Fig. 3). Transdisciplinary research teams that consider values and ethics in the design of their TD research may contribute to sustainable and just NRM through a shift in understanding and an exchange of knowledge built on a foundation of trust that potentially enables stakeholders to contribute and build their future.

In this discussion, we argue that careful TD research and practice design should explicitly account for ethics and values, as illustrated metaphorically in Figure 3. We suggest that participatory spaces that encourage explication and deliberation of shared values can "prepare and nourish the ground for diverse values" in which the Lang et al. (2012) "seeds of transdisciplinary design principles" can be put into practice (Figure 3). Furthermore, we suggest that these seeds should be sown by the "guiding hand of ethical principles." The better the ground is prepared, and continuously nourished, i.e., the more attention is paid to explicating and deliberating our values in TD teams within a particular SES context, the more likely we are to succeed in conducting TD research toward sustainable and just NRM (Fig. 3).

Fig. 3. A metaphorical heuristic building on the transdisciplinary design principles (Lang et al. 2012) proposing attentiveness to the role of value and ethics to guide transdisciplinary research as interpreted from our case studies. NRM, natural resource management. Illustration by Tammy Griffin.

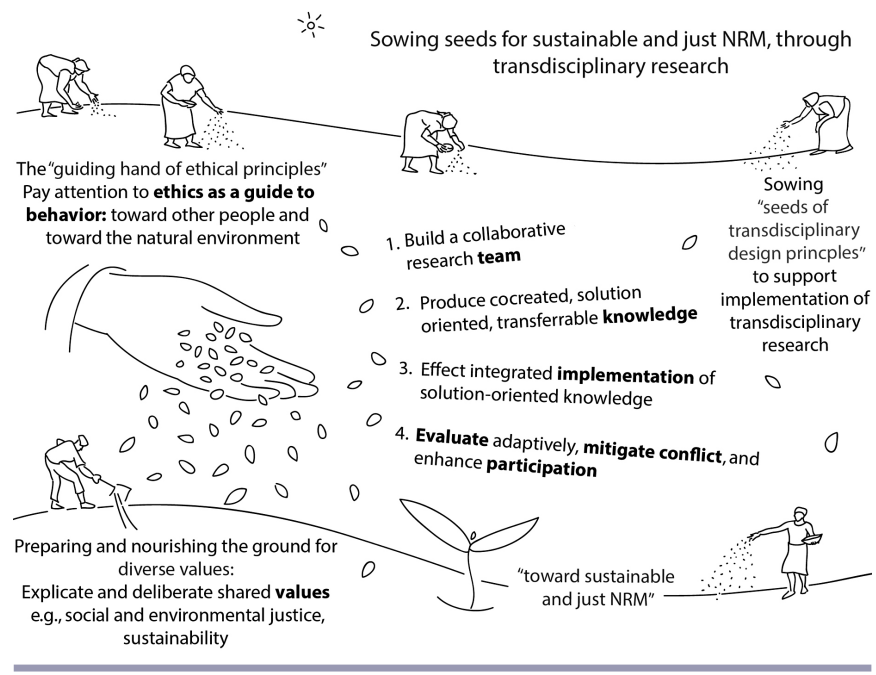

\section{CONCLUSION}

The core objective of this paper was to elucidate the contribution of TD research practice to sustainable and just NRM, drawing insights from the Eastern Cape, South Africa. We used the Lang et al. (2012) design principles as a reference point. We suggest that although consciously planned TD research alone is not sufficient to achieve sustainable and just NRM, it does contribute to a trajectory of change in that direction. Our case studies highlight the need to consider the role of values and ethics in designing and implementing TD processes. In several of our case studies, a shift in knowledge and understanding as a result of TD research practice enabled stakeholders to contribute more effectively to NRM. Processes of engagement helped to deepen the collective understanding of stakeholders of the complex social-ecological interactions and trade-offs, contributing to empowering participating stakeholders to better engage in critical decision making regarding NRM in their specific catchment. Thus, although these shifts did not necessarily equate to panaceas and solutions, they do nevertheless contribute to sustainable and just NRM.

Responses to this article can be read online at: http://www.ecologyandsociety.org/issues/responses. php/11077 


\section{Acknowledgments:}

The authors would like to acknowledge the generosity of the residents and participants in the various case studies discussed in the paper. The research would not be possible without the willingness to learn together of those who participated in the research journey. Jessica Cockburn (JC) acknowledges an NRF-DST Innovation Doctoral Research Scholarship and Rhodes University for the Henderson Scholarship, and for a Postdoctoral Fellowship. The financial assistance of the National Research Foundation (NRF) towards this research is hereby acknowledged. JC would further like to thank the Langkloof team from Living Lands for their contributions to the Langkloof case study, in particular Ancia Cornelius and Liz Metcalfe. Joana Bezerra would like to acknowledge the support of Dr Georgina Cundill. The funders of the case studies include the Department of Environmental Affairs: Natural Resource Management Programs, the South African Netherlands Programme for Alternatives in Development, the Water Research Commission, the National Research Foundation, and the Rhodes University Research Office. The authors are grateful to the anonymous reviewers who helped us improve our manuscript.

\section{LITERATURE CITED}

Agyeman, J., R. D. Bullard, and B. Evans. 2003. Just sustainabilities: development in an unequal world. Earthscan, London, UK.

Ainslie, A., and T. Kepe. 2002. Cattle ownership and production in the communal areas of the Eastern Cape, South Africa. Programme for Land and Agrarian Studies, Cape Town, South Africa.

Association for Water and Rural Development (AWARD). 2017. Annual report 2016/2017 financial year. Resilience in the LimpopoOlifants. AWARD, Hoedspruit, Limpopo, South Africa.

Audouin, M., R. Preiser, S. Nienaber, L. Downsborough, J. Lanz, and S. Mavengahama. 2013. Exploring the implications of critical complexity for the study of social-ecological systems. Ecology and Society 18(3):12. https://doi.org/10.5751/ES-05434-180312

Bennett, J., and H. Barrett. 2007. Rangeland as a common property resource: contrasting insights from communal areas of central Eastern Cape province, South Africa. Human Ecology 35 (1):97-112. https://doi.org/10.1007/s10745-006-9062-9

Biggs, R., M. Schlüter, D. Biggs, E. L. Bohensky, S. BurnSilver, G. Cundill, V. Dakos, T. M. Daw, L. S. Evans, K. Kotschy, A. M. Leitch, C. Meek, A. Quinlan, C. Raudsepp-Hearne, M. D. Robards, M. L. Schoon, L. Schultz, and P. C. West. 2012. Toward principles for enhancing the resilience of ecosystem services. Annual Review of Environment and Resources 37:421-448. https:// doi.org/10.1146/annurev-environ-051211-123836

Catalano, M. T., T. L. Leise, and T. J. Pfaff. 2009. Measuring resource inequality: the Gini coefficient. Numeracy 2(2):4. http:// dx.doi.org/10.5038/1936-4660.2.2.4

Chapin, III, F. S., M. E. Power, S. T. A. Pickett, A. Freitag, J. A. Reynolds, R. B. Jackson, D. M. Lodge, C. Duke, S. L. Collins, A. G. Power, and A. Bartuska. 2011. Earth stewardship: science for action to sustain the human-earth system. Ecosphere 2(8):1-20. https://doi.org/10.1890/ES11-00166.1
Cheng, A. S., and T. Randall-Parker. 2017. Examining the influence of positionality in evaluating collaborative progress in natural resource management: reflections of an academic and a practitioner. Society \& Natural Resources 30(9):1168-1178. https://doi.org/10.1080/08941920.2017.1295493

Cilliers, P. 2000. What can we learn from a theory of complexity? Emergence 2(1):23-33. https://doi.org/10.1207/s15327000em0201_03

Cilliers, P. 2001. Boundaries, hierarchies and networks in complex systems. International Journal of Innovation Management 5 (2):135-147. https://doi.org/10.1142/S1363919601000312

Cilliers, P. 2006. On the importance of a certain slowness. Emergence: complexity and organization 8(3):105-112.

Cilliers, P., H. C. Biggs, S. Blignaut, A. G. Choles, J. S. Hofmeyr, G. P. W. Jewitt, and D. J. Roux. 2013. Complexity, modeling, and natural resource management. Ecology and Society 18(3):1. https://doi.org/10.5751/ES-05382-180301

Clifford-Holmes, J. K. 2015. Fire and water: a transdisciplinary investigation of water governance. Dissertation. Institute for Water Research, Rhodes University, Grahamstown, South Africa.

Clifford-Holmes, J. K., C. G. Palmer, C. J. De Wet, and J. H. Slinger. 2016. Operational manifestations of institutional dysfunction in post-apartheid South Africa. Water Policy 18:998-1014. https://doi.org/10.2166/wp.2016.211

Clifford-Holmes, J. K., J. H. Slinger, C. De Wet, and C. G. Palmer. 2018. Modelling in the 'muddled middle': a case study of water service delivery in post-Apartheid South Africa. Pages 215-234 in C. García-Díaz and C. Olaya, editors. Social systems engineering: the design of complexity. John Wiley \& Sons, Hoboken, New Jersey, USA. https://doi.org/10.1002/9781118974414.ch11

Cockburn, J. 2018. Stewardship and collaboration in multifunctional landscapes: a transdisciplinary enquiry. Dissertation. Department of Environmental Science, Rhodes University, Grahamstown, South Africa.

Cockburn, J., and G. Cundill. 2018. Ethics in transdisciplinary research: reflections on the implications of 'science with society. ' Pages 81-97 in C. I. Macleod, J. Marx, P. Mnyaka, and G. J. Treharne, editors. The Palgrave handbook of ethics in critical research: stories from the field. Palgrave Macmillan, London, UK. https://doi.org/10.1007/978-3-319-74721-7 6

Cockburn, J., M. Rouget, R. Slotow, D. Roberts, R. Boon, E. Douwes, S. O'Donoghue, C. T. Downs, S. Mukherjee, W. Musakwa, O. Mutanga, T. Mwabvu, J. Odindi, A. Odindo, Ş. Procheş, S. Ramdhani, J. Ray-Mukherjee, Sershen, M. C. Schoeman, A. J. Smit, E. Wale, and S. Willows-Munro. 2016. How to build science-action partnerships for local land-use planning and management: lessons from Durban, South Africa. Ecology and Society 21(1):28. https://doi.org/10.5751/ES-08109-210128

Cundill, G., J. C. Bezerra, A. De Vos, and N. Ntingana. 2017. Beyond benefit sharing: place attachment and the importance of access to protected areas for surrounding communities. Ecosystem Services 28(B):140-148. https://doi.org/10.1016/j. ecoser.2017.03.011 
Cundill, G., D. J. Roux, and J. N. Parker. 2015. Nurturing communities of practice for transdisciplinary research. Ecology and Society 20(2):22. https://doi.org/10.5751/ES-07580-200222

de Laat, Z. 2017. The presumed increase of access due to redistribution of property rights in rural South Africa and analysis of policies and daily practices on land reform farms in the Langkloof. Thesis. Wageningen University, Wageningen, The Netherlands.

Dedeurwaerdere, T. 2013. Transdisciplinary sustainability science at higher education institutions: science policy tools for incremental institutional change. Sustainability 5(9):3783-3801. https://doi.org/10.3390/su5093783

Denney, J. M., P. M. Case, A. Metzger, M. Ivanova, and A. Asfaw. 2018. Power in participatory processes: reflections from multistakeholder workshops in the Horn of Africa. Sustainability Science 13(3):879-893. https://doi.org/10.1007/s11625-018-0533$\underline{\mathrm{x}}$

Department of Environmental Affairs. 2012. 2nd South Africa Environment Outlook. A Report on the State of the Environment. Executive Summary. Department of Environmental Affairs, Pretoria, South Africa.

Elundini Municipality. 2016. Integrated development plan 2016-2017. Elundini Municipality, South Africa. [online] URL: https://www.elundini.org.za/images/IDP/Final.pdf

Engeström, Y. 1987. Learning by expanding: an activity theory approach to developmental research. Orienta-Konsultit, Helsinki, Finland.

Engeström, Y. 2001. Expansive learning at work: toward an activity theoretical reconceptualization. Journal of Education and Work 14(1):133-156. https://doi.org/10.1080/13639080020028747

Environment and Rural Solutions (ERS). 2011. Umzimvubu catchment overview. Environment and Rural Solutions, Matatiele, Eastern Cape, South Africa.

Folke, C. 2006. Resilience: the emergence of a perspective for social-ecological systems analyses. Global Environmental Change 16(3):253-267. https://doi.org/10.1016/j.gloenvcha.2006.04.002

Foster, N., R. Ison, C. Blackmore, and K. Collins. 2018. Partnerships for action in river catchment governance. A case study in the Irwell, UK. The Open University, Milton Keynes, UK. [online] URL: http://oro.open.ac.uk/54030/

George, C., and M. G. Reed. 2017. Operatinalising just sustainability: towards a model for place-based government. Local Environment 22(9):1105-1123. https://doi.org/10.1080/13549839.2015.1101059

Government of South Africa. 2012. National development plan 2030: our future - make it work. Executive summary. National Planning Commission, The Presidency, Government of South Africa, Pretoria, South Africa.

Hamann, M., and V. Tuinder. 2012. Introducing the Eastern Cape: a quick guide to its history, diversity and future challenges. Stockholm Resilience Centre, Stockholm, Sweden. [online] URL: http://www.sapecs.org/wp-content/uploads/2013/11/Eastern-CapeBackground-Report.pdf

Hamer, N. G., L. Lipile, M. Lipile, L. Molony, X. Nzwana, J. O'Keeffe, S. E. Shackleton, M. Weaver, and C. G. Palmer. 2018.
Coping with water supply interruptions: Can citizen voice in transdisciplinary research make a difference? Water International 43(5):603-619. http://doi.org/10.1080/02508060.2018.1497863

Hebinck, P., D. Fay, and K. Kondlo. 2011. Land and agrarian reform in South Africa's Eastern Cape Province: caught by continuities. Journal of Agrarian Change 11(2):220-240. https:// doi.org/10.1111/j.1471-0366.2010.00297.x

Ison, R. L. 2010. Systems practice. How to act in a climate-change world. Springer, London, UK.

Jahn, J., M. Bergmann, and F. Keil. 2012. Transdisciplinarity: between mainstreaming and marginalization. Ecological Economics 79:1-10. https://doi.org/10.1016/j.ecolecon.2012.04.017

Jankielsohn, R., and A. Duvenhage. 2017. Radical land reform in South Africa - a comparative perspective? Journal for Contemporary History 42(2):1-23 https://dx.doi.org/10.18820/24150509/ JCH42.v2.1

Kabogo, J. E., E. P. Anderson, P. Hyera, and G. Kajanja. 2017. Facilitating public participations in water resources management: reflections from Tanzania. Ecology and Society 22(4):26. https:// doi.org/10.5751/ES-09739-220426

Kingsford, R. T., and H. C. Biggs. 2011. Adaptive management guidelines for effective conservation of freshwater ecosystems in and around protected areas of the world. IUCN WCPA Freshwater Taskforce, Australian Wetlands and Rivers Centre, Sydney, Australia. ISBN 978-0-7334-3061-9.

Lang, D. J., A. Wiek, M. Bergmann, M. Stauffachers, P. Martens, P. Moll, M. Swilling, and C. J. Thomas. 2012. Transdisciplinary research in sustainability science: practice, principles and challenges. Sustainability Science 7(1):25-43. https://doi. org/10.1007/s11625-011-0149-X

Lenoble, J., and M. Maesschalck. 2010. Democracy, law and governance. Routledge, London, UK. https://doi. org/10.4324/9781315576435

Living Lands. 2017. Eight years on the landscape: the current state of Living Lands. Living Lands, Cape Town, South Africa. http:// livinglands.co.za/wp-content/uploads/2017/05/Eight-Years-on-theLandscape.pdf

Luthe, T., 2017. Success in transdisciplinary sustainability research. Sustainability 9(1):71. http://dx.doi.org/10.3390/ $\underline{\text { su9010071 }}$

Mander, M., J. Blignaut, M. van Niekerk, R. Cowling, M. Horan, D. Knoesen, A. Mills, M. Powell, and R. Schulze. 2010. Baviaanskloof - Tsitsikamma payment for ecosystem services: a feasibility assessment: synthesis report. SANBI, CAPE, Working for Water, and UNDP. Future Works, Everton, South Africa.

Max-Neef, M. A. 2005. Foundations of transdisciplinarity. Ecological Economics 53(1):5-16. https://doi.org/10.1016/j. ecolecon.2005.01.014

McClure, A. 2012. Opportunity and connectivity: selecting land managers for involvement in a conservation corridor linking two protected areas in the Langkloof Valley, South Africa. Thesis. Rhodes University, Grahamstown, South Africa.

Molony, L. 2014. Water security amongst impoverished households in the Sundays River Valley Municipality: community experiences 
and perspectives. Thesis. Department of Environmental Science, Rhodes University, Grahamstown.

Mucina, L., and M. C. Rutherford, editors. 2006. The vegetation of South Africa, Lesotho and Swaziland. Strelitzia 19, South African National Biodiversity Institute, Pretoria, South Africa.

Muller, M. 2013. Linking institutional and ecological provisions for wastewater treatment discharge in a rural municipality, Eastern Cape, South Africa. Thesis. Institute for Water Research, Rhodes University, Grahamstown, South Africa.

Odume, O. N., and C. De Wet. 2016. The role of environmental ethics in social-ecological systems and water resource management. WRC report no. 2342/1/16. Water Research Commission, Pretoria, South Africa.

Ostrom, E. 1990. Governing the commons. Cambridge University Press, Cambridge, New York, New York, USA.

Pain, R., and P. Francis. 2003. Reflections on participatory research. Area 35(1):46-54. https://doi.org/10.1111/1475-4762.00109

Palmer, A. R., and A. Ainslie. 2006. Arid rangeland production systems of Southern Africa. Secheresse 17(1\&2):98-104. ISSN 1777-5922.

Palmer, A. R., and J. Bennett. 2013. Degradation of communal rangelands in South Africa: towards an improved understanding to inform policy. African Journal of Range and Forage Science 30 (1-2):57-63. https://doi.org/10.2989/10220119.2013.779596

Palmer, C. G. 1999. The application of ecological research to the development of a new South African water law. Journal of the North American Benthological Society 18(1):132-142. https://doi. org/10.2307/1468013

Palmer, C. G., R. Biggs, and G. Cumming. 2015. Applied research for enhancing human well-being and environmental stewardship: using complexity thinking in Southern Africa. Ecology and Society 20(1):53. https://doi.org/10.5751/ES-07087-200153

Palmer, C. G., J. Gothe, C. Mitchell, C. Reidy, K. Sweetapple, S. McLaughlin, G. Hose, M. Lowe, H. Goodall, T. Green, D. Sharma, S. Fane, K. Brew, and P. Jones. 2007. Finding integration pathways: developing a transdisciplinary (TD) approach for the Upper Nepean Catchment. Proceedings of the 5th Australian Stream Management Conference. Charles Sturt University, Thurgoona, New South Wales, Australia. [online] URL: http:// www.csu.edu.au/_data/assets/pdf_file/0011/748415/Palmer_Carolyn_306. pdf

Palmer, C. G., and V. Munnik. 2018. Practising adaptive IWRM. Integrated water resources management (IWRM) in South Africa: towards practising a new paradigm. Report No. K5/2248. Water Research Commission, Pretoria, South Africa. ISBN: 978-1-4312-0983-5.

Palmer, C. G., K. Rogers, H. Holleman, and M. G. Wolff. 2018. How to use strategic adaptive management (SAM) and the adaptive planning process (APP) to build a shared catchment future. Handbook 8. Project K5/2248. Water Research Commission, Pretoria, South Africa.

Perret, S., J. Carstens, R. Randela, and S. Moyo. 2000. Activity systems and livelihoods in Eastern Cape Province rural areas (Transkei): household typologies as socio-economic contributions to a landcare project. CIRAD-Tera num 2000/28. Department of Agricultural Economics, Extension and Rural Development, University of Pretoria, Pretoria, South Africa.

Pohl, C., and G. H. Hadorn. 2008. Methodological challenges of transdisciplinary research. Natures Sciences Sociétés 16 (2):111-121. https://doi.org/10.1051/nss:2008035

Polk, M. 2014 Achieving the promise of transdisciplinarity: a critical exploration of the relationship between transdisciplinary research and societal problem solving. Sustainability Science 9 (4):439-451. https://doi.org/10.1007/s11625-014-0247-7

Popa, F., M. Guillermin, and T. Dedeurwaerdere. 2015. A pragmatist approach to transdisciplinarity in sustainability research: from complex systems theory to reflexive science. Futures 65:45-56. https://doi.org/10.1016/j.futures.2014.02.002

Powell, M., H. Biggs, M. Braack, and the Ntabelanga and Lalini Ecological Infrastructure Project team. 2018. Ntabelanga and Lalini ecological infrastructure project. Pages 83-87 in $\mathrm{S}$. Nicklin, B. Cornwell, and L. Trowbridge, editors. A better world volume 3: ensure access to water and sanitation for all. Actions and commitments to the sustainable development goals. Tudor Rose, Leicester, UK. ISBN 978-0-9956487-3-9.

Preiser, R., P. Cilliers, and O. Human. 2013. Deconstruction and complexity: a critical economy. South African Journal of Philosophy 32(3):261-273. https://doi.org/10.1080/02580136.2013.837656

Rasch, S., T. Heckelei, H. Storm, R. Oomen, and C. Naumann. 2017. Multi-scale resilience of communal rangeland system in South Africa. Ecological Economics 131:129-138. https://doi. org/10.1016/j.ecolecon.2016.08.012

Reed, M. S., L. C. Stringer, A. J. Dougill, J. S. Perkins, J. R. Atlhopheng, K. Mulale, and N. Favretto. 2015. Reorienting land degradation towards sustainable land management: linking sustainable livelihoods with ecosystems services in rangeland systems. Journal of Environmental Management 151:472-485. https://doi.org/10.1016/j.jenvman.2014.11.010

Reid, H., L. Sahlén, J. Stage, and J. MacGregor. 2008. Climate change impacts on Namibia's natural resources and economy. Climate Policy 8(5):452-466. https://doi.org/10.1080/14693062.2$\underline{008.9685709}$

Rhodes University Transdisciplinary Research Group. 2016. Transdisciplinary research exploratory training workshop for postgraduate scholars. Final report. Centre for Postgraduate Studies, Rhodes University, Grahamstown. [online] URL: https:// www.ru.ac.za/media/rhodesuniversity/content/iwr/documents/ Final Report RU-TD workshop May 2016.pdf

Ribot, J. C. 2006. Choose democracy: environmentalists' sociopolitical responsibility. Global Environmental Change 16 (2):115-119. https://doi.org/10.1016/j.gloenvcha.2006.01.004

Rittel, H. W. J., and M. M. Webber. 1973. Dilemmas in a general theory of planning. Policy Sciences 4(2):155-169. https://doi. org/10.1007/BF01405730

Rockström, J., W. Steffen, K. Noone, Å. Persson, F. S. Chapin, III, E. Lambin, T. M. Lenton, M. Scheffer, C. Folke, H. Schellnhuber, B. Nykvist, C. A. De Wit, T. Hughes, S. van der Leeuw, H. Rodhe, S. Sörlin, P. K. Snyder, R. Costanza, U. Svedin, M. Falkenmark, L. Karlberg, R. W. Corell, V. J. Fabry, J. Hansen, 
B. Walker, D. Liverman, K. Richardson, P. Crutzen, and J. Foley. 2009. Planetary boundaries: exploring the safe operating space for humanity. Ecology and Society 14(2):32. https://doi. org/10.5751/ES-03180-140232

Rogers, K. H., and R. Luton. 2011. Strategic adaptive management as a framework for implementing integrated water resource management in South Africa. Water Research Commission Report No. KV 245/10. Water Research Commission, Pretoria, South Africa.

Rogers, K. H., R. Luton, H. Biggs, R. Biggs, S. Blignaut, A. G. Choles, C. G. Palmer, and P. Tangwe. 2013. Fostering complexity thinking in action research for change in social-ecological systems. Ecology and Society 18(2):31. http://dx.doi.org/10.5751/ ES-05330-180231

Rossman, G. B., and S. F. Rallis. 2010. Everyday ethics: reflections on practice. International Journal of Qualitative Studies in Education 23(4):379-391. https://doi.org/10.1080/09518398.2010.492813

Sandhage-Hofmann, A., E. Kotzé, L. van Delden, M. Dominiak, H. J. Fouché, H. C. van der Westhuizen, R. J. Oomen, C. C. du Preez, and W. Amelung. 2015. Rangeland management effects on soil properties in the savanna biome, South Africa: a case study along grazing gradients in communal and commercial farms. Journal of Arid Environments 120:14-25. https://doi.org/10.1016/ j.jaridenv.2015.04.004

Sannino, A., and Y. Engeström. 2017. Co-generation of societally impactful knowledge in change laboratories. Management Learning 48(1):80-96. https://doi.org/10.1177/1350507616671285

Schreiner, B. 2013. Why has the South African National Water Act been so difficult to implement? Water Alternatives 6 (2):239-245.

Seekings, J. 2008. The continuing salience of race: discrimination and diversity in South Africa. Journal of Contemporary African Studies 26(1):1-25. https://doi.org/10.1080/02589000701782612

Shackleton, C. M., S. E. Shackleton, E. Buiten, and N. Bird. 2007. The importance of dry woodlands and forests in rural livelihoods and poverty alleviation in South Africa. Forest Policy and Economics 9(5):558-577. https://doi.org/10.1016/j.forpol.2006.03.004

Shackleton, C. M., S. E. Shackleton, and B. Cousins. 2001. The role of land-based strategies in rural livelihoods: the contribution of arable production, animal husbandry and natural resource harvesting in communal areas in South Africa. Development Southern Africa 18(5):581-604. https://doi.org/10.1080/0376835$\underline{0120097441}$

Sisitka, L., M. Ntshudu, N. Hamer, and A. de Vos. 2016. Ntabelanga (Laleni) stakeholder analysis. The Department of Environmental Affairs - Natural Resource Management, Pretoria, South Africa.

Statistics South Africa. 2012. Census 2011. Statistics South Africa, Pretoria, South Africa.

Swilling, M., and E. Annecke. 2012. Just transitions. UCT Press, Cape Town, South Africa.

Till, K. E. 2012. Wounded cities: memory-work and a place-based ethics of care. Political Geography 31:3-14. https://doi. org/10.1016/j.polgeo.2011.10.008
Van Breda, J., J. Musango, and A. Brent. 2016. Undertaking individual transdisciplinary $\mathrm{PhD}$ research for sustainable development: case studies from South Africa. International Journal of Sustainability in Higher Education 17(2):150-166. https://doi.org/10.1108/IJSHE-07-2014-0107

Van Breda, J., and M. Swilling. 2019. The guiding logics and principles for designing emergent transdisciplinary research processes: learning experiences and reflections from a transdisciplinary urban case study in Enkanini informal settlement, South Africa. Sustainability Science 14(3):823-841. https://doi.org/10.1007/s11625-018-0606-X

Van Kerkhoff, L., and L. Lebel. 2006. Linking knowledge and action for sustainable development. Annual Review of Environment and Resources 31:445-477. https://doi.org/10.1146/ annurev.energy.31.102405.170850

Van Tol, J., W. Akpan, G. Kanuka, S. Ngesi, and D. Lange. 2016. Soil erosion and dam dividends: science facts and rural 'fiction' around the Ntabelanga dam, Eastern Cape, South Africa. South African Geographical Journal 98(1):169-181. http://doi. org/10.1080/03736245.2014.977814

Vindrola-Padros, C., T. Pape, M. Utley, and N. J. Fulop. 2017. The role of embedded research in quality improvement: a narrative review. BMJ Quality and Safety 26(1):70-80. https://doi. org/10.1136/bmjqs-2015-004877

Von Bormann, T., and M. Gulati. 2014. The food energy water nexus: understanding South Africa's most urgent sustainability challenge. World Wide Fund-South Africa, Cape Town, South Africa.

Wals, A., N. van der Hoeven, and H. Blanken. 2009. The acoustics of social learning: designing learning processes that contribute to a more sustainable world. Wageningen Academic, Netherlands, The Netherlands.

Weaver, M. J. T., J. O'Keeffe, N. Hamer, and C. G. Palmer. 2017. Water service delivery challenges in a small South African municipality: identifying and exploring key elements and relationships in a complex social-ecological system. Water $S A 43$ (3):398-408. https://doi.org/10.4314/wsa.v43i3.04

Westaway, A. 2012. Rural poverty in the Eastern Cape Province: legacy of apartheid or consequence of contemporary segregationism? Development Southern Africa 29(1):115-125. http://doi.org/10.1080/0376835X.2012.645646

Williams, B., D. Mayson, R. De Satge, S. Epstein, and T. Semwayo. 2008. Extension and smallholder agriculture. Key issues from a review of the literature. Phuhlisani, Cape Town, South Africa.

Williamson, G. R., and S. Prosser. 2002. Action research: politics, ethics and participation. Journal of Advanced Nursing 40 (5):587-593. https://doi.org/10.1046/j.1365-2648.2002.02416.x

Wolff, M. G. 2019. Bridging the gap - hearing silenced voices. A learning-centred process to sustainable land rehabilitation, and natural resource management. Thesis. Institute for Water Research, Rhodes University, Grahamstown, South Africa.

Yin, R. K. 2009. Case study research: design and methods. SAGE, Thousand Oaks, California, USA. 